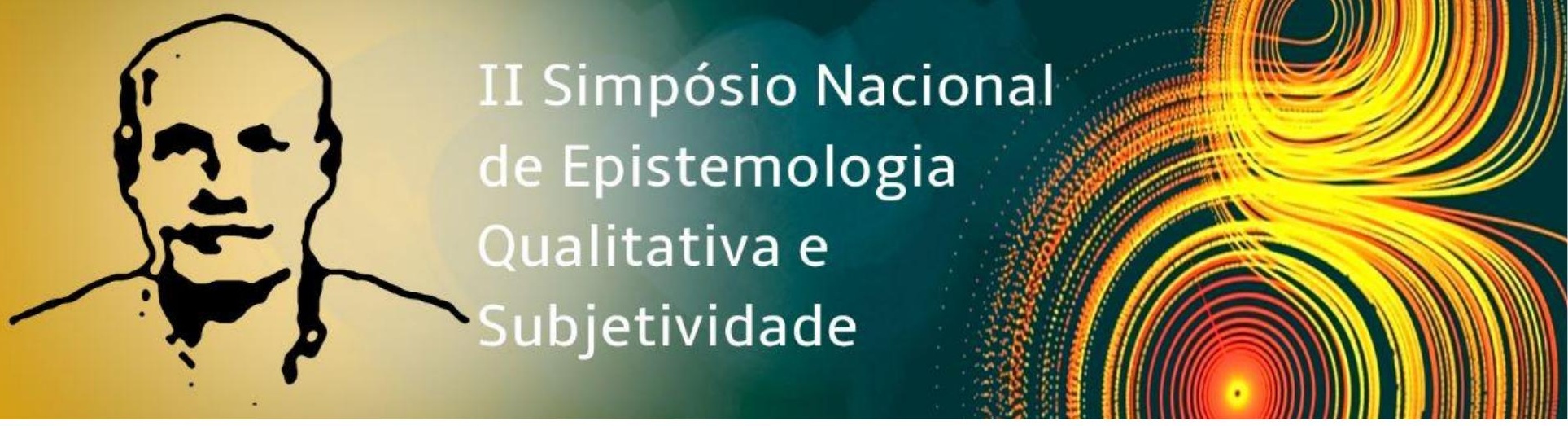

Eixo temático: A dimensão subjetiva da deficiência no processo de inclusão escolar

\title{
Inclusão Social, Subjetividade e Transtorno do Espectro Autista: Um Estudo de Caso
}

Larissa Lopes Rocha ${ }^{1}$, UniCEUB, larissa.1r@sempreceub.com Daniel Magalhães Goulart ${ }^{2}$, UniCEUB, daniel.goulart@ ceub.edu.br

\section{Resumo}

Alunos com necessidades educacionais especiais têm garantido por lei o direito à educação na rede de ensino regular. Porém, ainda assim existem muitas barreiras nesse processo devido à falta de recursos pedagógicos e de respeito às diferenças (WEISHEIMER, 2017). É certo que o processo inclusivo vai além da integração das pessoas em questão dentro de determinado meio, e, diante disso, Leal (2011) aponta uma ressignificação da vida coletiva no espaço escolar desejada a partir do modelo inclusivo, possibilitando a criação de novos significados baseados no respeito à todo tipo de diferença, além do devido reconhecimento da singularidade como uma condição inerente ao indivíduo. Dessa forma, esse trabalho teve como objetivo compreender os processos subjetivos produzidos por uma criança com Transtorno do Espectro Autista (TEA) frente à inclusão social. Utilizou-se na pesquisa o método construtivo-interpretativo, ancorado na Epistemologia Qualitativa de González Rey (2005). Teve-se como referencial teórico a Teoria da Subjetividade, também proposto por González Rey, que entende a subjetividade como sistema simbólico-emocional primordial no estudo dos processos humanos (GONZÁLEZ REY \& MITJÁNS MARTINEZ, 2017). A pesquisa foi desenvolvida levando-se em conta a unidade entre teoria e prática durante três meses, com encontros realizados quinzenalmente com uma criança diagnosticada com TEA. Primou-se pelo cuidado no estabelecimento de um vínculo entre participante e pesquisadora. Os instrumentos utilizados foram dinâmicas conversacionais, desenho da família/escola, complementação de frases, adaptação do jogo dos sentimentos e composição. As construções da informação são apresentadas em dois eixos temáticos: (1) Processos subjetivos da criança frente à inclusão social; (2) Processos subjetivos da criança relacionados a si e aos seus 


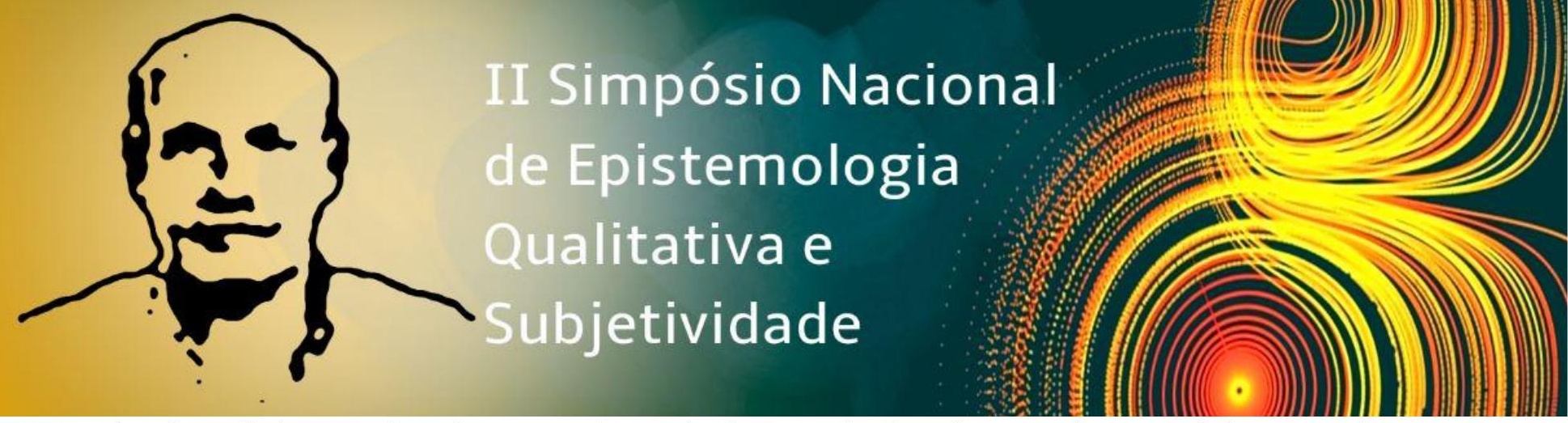

vínculos afetivos mais relevantes. A partir das conclusões da pesquisa, conclui-se que é importante superar a noção de "criança problema", visto que é plenamente possível que a criança diagnosticada com TEA se desenvolva subjetivamente, desde que participe de contextos que colaborem para a construção desse complexo processo. Isto posto, é essencial a elaboração e valorização de estratégias voltadas para a compreensão de processos singulares advindos de pessoas com transtornos, tirando o foco da sintomatologia, diagnóstico e necessidade de medicalização. Enfatiza-se, assim, o lugar ativo desses indivíduos, considerando-os a partir de seus recursos subjetivos e seus modos singulares de ser e existir aspectos que vão muito além da reificação do diagnóstico.

Palavras chave: Transtorno do Espectro Autista; subjetividade; inclusão social.

\section{Referências}

GONZÁLEZ REY, F. (2005). Pesquisa Qualitativa e Subjetividade: os processos de construção da informação. São Paulo: Cengage Learning.

GONZÁLEZ REY, F \& MITJÁNS MARTÍNEZ, A. (2017) Subjetividade teoria, epistemologia e método. São Paulo: Alínea.

LEAL, C. E. G. (2011). O sentido subjetivo da inclusão para o sujeito com síndrome de Asperger. Dissertação (Mestrado em Educação). Universidade Federal do Piauí, Centro de Ciências da Educação, Programa de Pós-Graduação em Educação: Teresina.

WEISHEIMER, I. C. (2017). Criança Com A Síndrome De Asperger: Esteriótipos, Preconceitos e Discriminação No Âmbito Escolar. Revista Thêma et Scientia, 7(2), 89-106. 